University of Nebraska - Lincoln

DigitalCommons@University of Nebraska - Lincoln

Papers in Systematics \& Biological Diversity

Papers in the Biological Sciences

$9-1-1897$

\title{
Phylogeny and Taxonomy of the Angiosperms
}

Charles E. Bessey

University of Nebraska - Lincoln

Follow this and additional works at: https://digitalcommons.unl.edu/bioscisystematics

Part of the Botany Commons

Bessey, Charles E., "Phylogeny and Taxonomy of the Angiosperms" (1897). Papers in Systematics \& Biological Diversity. 9.

https://digitalcommons.unl.edu/bioscisystematics/9

This Article is brought to you for free and open access by the Papers in the Biological Sciences at DigitalCommons@University of Nebraska - Lincoln. It has been accepted for inclusion in Papers in Systematics \& Biological Diversity by an authorized administrator of DigitalCommons@University of Nebraska - Lincoln. 


\section{Botanical Gazette \\ SEPTEMBER $\quad 1897$}

\section{PHYLOGENY AND TAXONOMY OF THE ANGIOSPERMS. ${ }^{\mathrm{I}}$}

CHARI, LS LE. BESSHY.

IT is unnecessary for me to state at the outset what is evident to every botanist, that it is as yet impossible to present a complete phylogeny of the angiosperms. Phytopalæontology is too young a science, and the materials with which it deals are yet far too scanty to have given us direct evidence as to the phylogeny of all families of plants. No one can trace with great certainty from the fossil remains of plants yet discovered the genealogy of any considerable portion of the vegetable kingdom. It will be many a year before the direct evidence we so much desire will leave no considerable gaps to be filled by skillful interpolation. However, after making all due allowance for the imperfection of the record, there are many facts as to past vegetation which are well established. Thus, we know that the earliest plants were simple, homogeneous-celled, aquatic organisms. We know that ferns and gymnosperms preceded angiosperms. We know that the angiosperms which first appeared were of lower types, and that the highest types known today were wanting until very late in geological time.

It is true, moreover, that we are not confined to the direct evidence furnished by the palæontological record. In the individual development of every plant (ontogenesis) there is a

${ }^{\mathrm{I}}$ Address of the retiring President of the Botanical Society of America, delivered at Toronto, August I7, I897.

I897] 
recapitulation of its ancestral development (phylogenesis). A critical study of the development of the individual must throw light upon the past history of the species. When we know every step in the formation of each plant we shall be able to trace the phylogeny of every species. Here again we have to face the fact that our knowledge is still quite fragmentary, and that on this account the results are not as definite as we could wish. And yet, when we bring together what we know of the ontogeny of plants here and there in the higher groups, we are able to make out with much certainty not a little as to their phylogeny. To the details regarding these results I shall advert somewhat later.

There is still another line of inquiry open to us, namely, the morphological, in which account is taken of the varying development of homologous tissues, members, and organs. Rightly interpreted, the results of morphological studies are of very high importance in determining genetic relationships. When differences in homologous parts are regarded as but the expression of variation from a common form, they become indices of relationship, and when these indices, obtained from all the tissues, members, and organs of a group of plants, are judiciously considered, they mark out lines of descent with great distinctness.

We have thus open to us three lines of investigation in the study of the phylogeny of plants, namely, ( I ) the historical, in which the materials are supplied by phytopalæontology, (2) the ontogenetic, in which the development of the individual supplies us with the necessary data, and (3) the morphological, in which the different development of homologous parts is our index of relationship. In this paper I purpose to bring these three lines of investigation to bear upon the problem of the phylogeny of the angiosperms.

GENERAL RESULTS FROM PHYTOPALEONTOLOGY.

In the Devonian period plants underwent such modifications that we pretty clearly recognize the three types which constitute 
the present classes of the pteridophytes,- the ferns, joint-rushes, and lycopods. There appears to be no doubt that heterospory was attained by some of the Devonian pteridophytes. The Lepidodendreæ were quite certainly heterosporous, and possibly the Psilophyteæ should be admitted also. Certain it is that the conifers of this period were heterosporous.

In the Carboniferous and Permian the species and genera of then existing types were multiplied, and the cycads, another heterosporous type, were added. This tendency to heterospory soon resulted in the appearance of plants referred by some authors to the monocotyledons. It is pretty certain at any rate that monocotyledons appeared late in the Palæozoic period or early in the Mesozoic. Of dicotyledons no fossils have been determined with certainty earlier than the Cretaceous, in which period they were evidently quite abundant.

If now we examine with some detail the fossil remains of the angiosperms we find that the earliest recognized were monocotyledons with superior ovaries (Palæospatha, Spirangium, Yuccites, from the Permocarboniferous and the early Mesozoic). Making due allowance for possible errors of determination we find that by the end of the Jurassic period the monocotyledons were probably represented by members of the groups (orders) Apocarpæ, Coronarieæ, Calycinæ, and Glumaceæ. To these we may add, in the Cretaceous, a few representatives of the Epigynæ. In the Tertiary the plants determined are referred to the Apocarpæ, Coronarieæ, Nudifloræ, Calycinæ, Glumaceæ, Hydrales, and Epigynæ. It is interesting to note that the monocotyledonous plants of the Tertiary have been referred mainly to the hypogynous orders, and that none have been identified as representing the Microsperma. Apparently the evolution of the monocotyledons began with hypogynous species and proceeded toward those in which epigyny is most marked. Orchids are doubtless of very late evolution, so late in fact that none have been preserved as fossils.

The foregoing facts are presented below in tabular form, the per cent. of representation of each group being given for each 
period. The data for this table are derived from Schimper, ${ }^{2}$ Lesquereux, ${ }^{3}$ and Durand. ${ }^{4}$

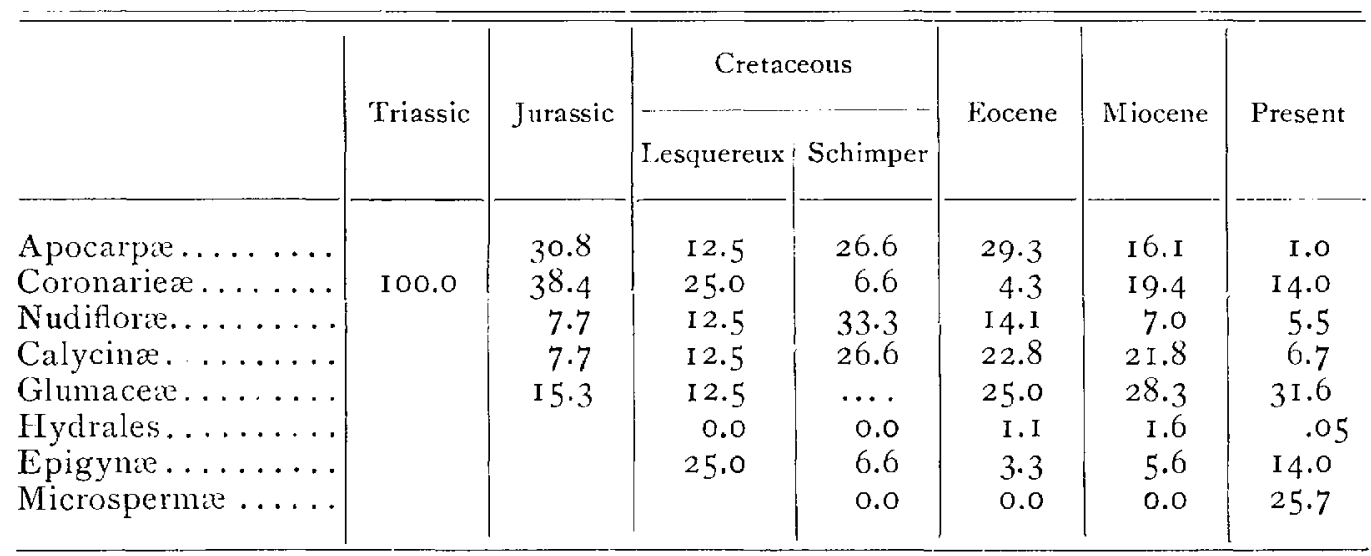

The history of the dicotyledons, as far as yet made out, is relatively simple. In the Cretaceous we find that from 90 to 95 per cent. of the known species may be referred to the two primitive groups (orders) Thalamifloræ and Calycifloræ. Taking Schimper's results, we find that nearly 60 per cent. are referable to the Thalamifloræ, representing nearly equally the groups (sub-orders) Ranales, Caryophyllales, and Malvales. The less important groups, Parietales, Polygalales, Geraniales, and Guttiferales, have not yet appeared; at least no representatives have been certainly recognized.

The Calycifloræ are represented by species of Rosales, Myrtales, Celastrales, Sapindales, and Umbellales. Here the numbers are quite unequal, ranging from about io per cent. for Myrtales and Umbellales, to I 3 per cent. for Rosales, 26 per cent. for Celastrales, and 40 per cent. for Sapindales. The Heteromeræ and Bicarpellatæ were scarcely represented, Schimper recording but a single species each of Ericales, Ebenales, and Gentianales. If we make use of the data brought together by Lesquereux, ${ }^{5}$ we find little change in the general results. There is here a slight preponderance of Calycifloræ

${ }^{3}$ Traité de Palæontologie Végétale. 1869-1874.

3 The Flora of the Dakota Group. I 89 I.

${ }^{4}$ Index Generum Phanerogamarum. 1888.

5 The Flora of the Dakota Group. I891. 
over the Thalamifloræ, $5^{2}$ per cent. of the former to 48 per cent. of the latter. We note, moreover, that the Ranales include nearly 50 per cent. of the Thalamifloræ, the Caryophyllales 16 per cent., and the Malvales 34 per cent. In the Calycifloræ the Myrtales have but 4 per cent., the Umbellales i 2 per cent., the Rosales 24 per cent., and the Celastrales and Sapindales about 30 per cent. each. The Heteromeræ are represented by a few species of Primulales, Ericales, and Ebenales, and there are no Bicarpellatæ whatever. Of the Inferæ there are eight species of Rubiales. It will be instructive to place these results side by side in tabular form.

\begin{tabular}{|c|c|c|c|c|c|c|}
\hline & \multicolumn{3}{|c|}{$\begin{array}{l}\text { Per cent. of species } \\
\text { Schimper }\end{array}$} & \multicolumn{3}{|c|}{$\begin{array}{l}\text { Per cent. of species } \\
\text { Lesquereux }\end{array}$} \\
\hline 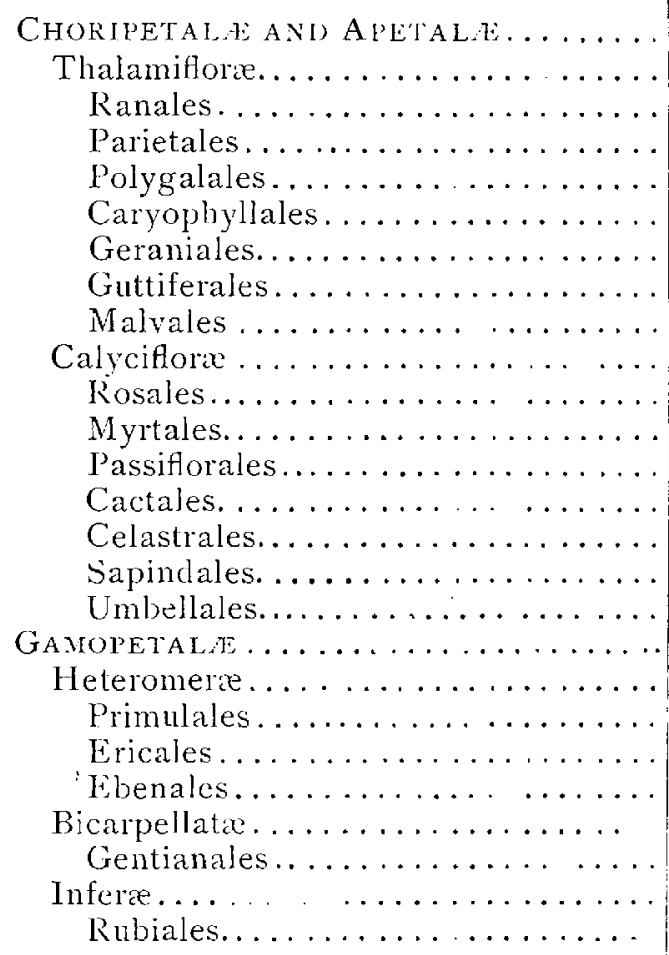 & 96 & $\begin{array}{c}33 \\
0\end{array}$ & $\begin{array}{c}34 \\
0 \\
0 \\
32 \\
0 \\
0 \\
34 \\
\\
13 \\
10 \\
0 \\
0 \\
26 \\
40 \\
10 \\
\\
0 \\
50 \\
50 \\
100 \\
0\end{array}$ & 92 & $\begin{array}{c}0 \\
28\end{array}$ & $\begin{array}{c}50 \\
0 \\
0 \\
16 \\
0 \\
0 \\
34 \\
\\
24 \\
4 \\
0 \\
0 \\
30 \\
30 \\
12\end{array}$ \\
\hline
\end{tabular}

The significance of these data may be made still more evident by the following diagrams which are drawn to the same proportions $(f g \cdot I)$.

Attention may well be called to the close agreement between the results reached by Schimper and Lesquereux. According to 
Schimper, 96 per cent. of the species are apetalous and choripetalous, and but 4 per cent. gamopetalous, while according to Lesquereux 92 per cent. are apetalous and choripetalous, and 8 per cent. gamopetalous. Again, we find that, according to

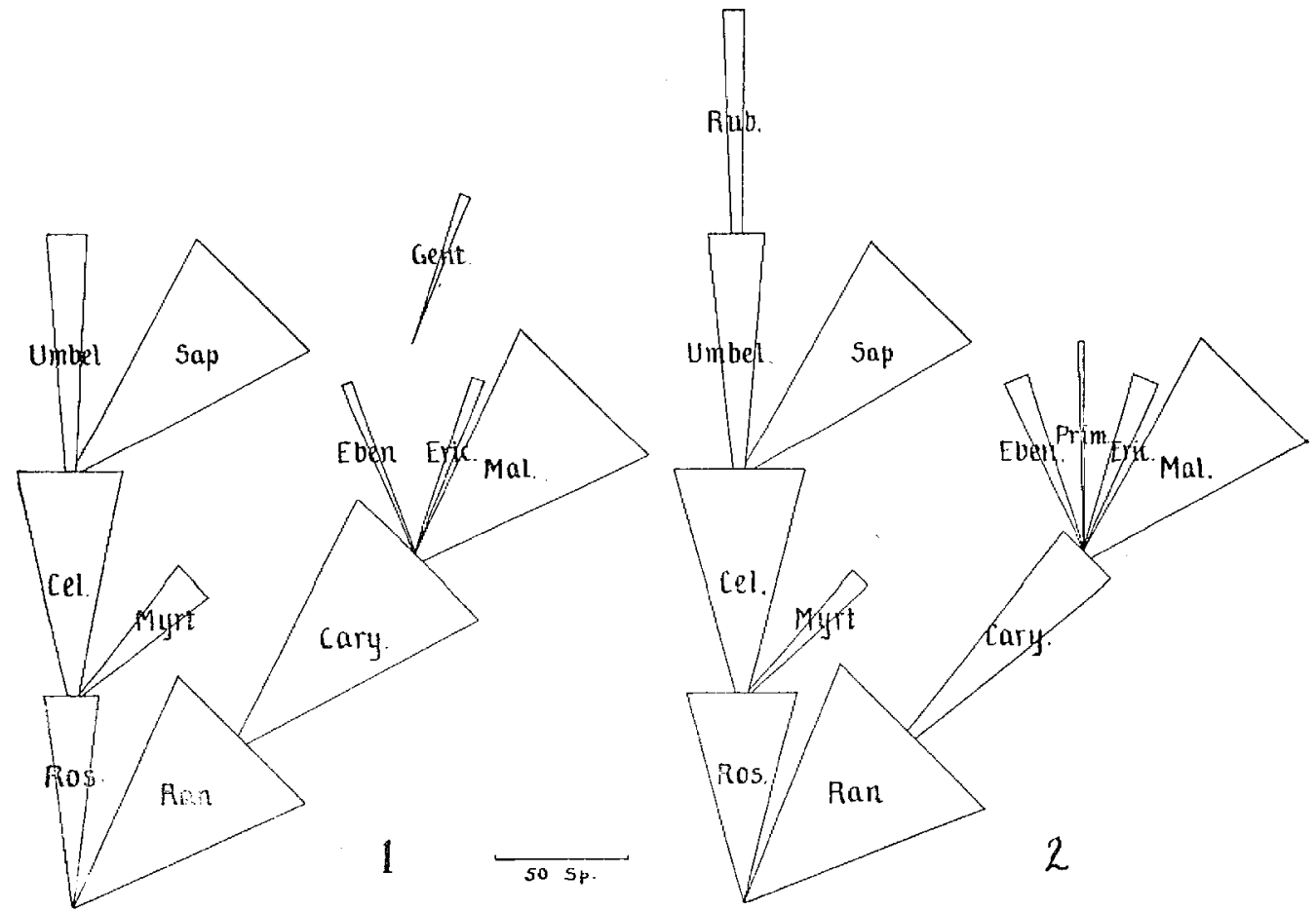

Fig. I. Diagrammatic comparison of the groups of Cretaceous dicotyledons : I. according to Schimper; 2. according to Lesquereux. The widths of the triangles indicate relative numbers of species.

Schimper, 80 per cent. of the species have superior ovaries and 20 per cent. inferior ovaries, and these are exactly the proportions in Lesquereux's list. It is worthy of notice, also, that the two lists agree almost exactly in the sub-orders represented, and in the relative number of species in each. Thus in the Thalamifloræ in both lists the Ranales and Malvales are more numerously represented than are the Caryophyllales; in the Calycifloræ, the parallelism is still more marked, the lowest numbers occurring in both lists in Myrtales and Umbellales, intermediate numbers in Rosales, and the highest in Celastrales and Sapindales.

In one particular there is a marked difference between the two lists. Schimper's contains 64 per cent. of apetalous plants, with 
but 36 per cent. of those having petals, while Lesquereux's list contains but 42.5 per cent. of apetalous, and 57.5 per cent. of petalous plants. This result is so directly contrary to the commonly accepted notions as to the composition of the dicotyledonous flora of the Cretaceous period that it is worthy of careful consideration. It is possible that this unexpected predominance of the petalous plants is merely the result of the more careful and exhaustive study of the Cretaceous fossils of America, and that when we know more fully the fossil plants of the Cretaceous elsewhere we shall no longer suppose the earlier dicotyledons to have been mainly apetalous. The suggestion is seen to be quite probable when we observe that Lesquereux's earlier report ${ }^{6}$ contained $6 r$ per cent. of apetalous to 39 per cent. of petalous plants. Here very certainly the work of twelve or fourteen years upon one formation reversed the numerical proportions between the apetalous and the petalous plants.

In the Eocene period, if we follow Schimper, we find that the families of dicotyledons had risen from twenty-one in the Cretaceous to forty, and that the species were more than three and and one-half times as numerous. The gamopetalous species had risen to I 4 per cent., and of the remainder considerably more than one half ( 57.5 per cent.) were petalous. For the whole of the dicotyledons the per cent. of petal-bearing species had risen to nearly 64. And yet in spite of all this increase we find that the per cent. of species with inferior ovaries remained as in the Cretaceous, or nearly so.

Many families were added in the sub-orders previously represented, and some new sub-orders appeared. Thus in Ranales there were added the Anonaceæ and the Nymphæaceæ. The sub-orders Polygalales and Geraniales appeared, the first represented by the Pittosporaceæ, and the second by the Rutaceæ. To the Malvales were added the Sterculiaceæ and Tiliaceæ; to the Rosales, the three leguminous families (Mimosaceæ, Cæsalpiniaceæ, and Papilionaceæ); to the Celastrales, the Ilicineæ, Celastraceæ, Rhamnaceæ, and Thymelæaceæ; to the Umbellales,

${ }^{6}$ The Cretaceous Flora. U. S. Geol. Survey of the Territories. I874. 
the Cornaceæ; to the Ebenales, the Sapotaceæ, and Styracaceæ; and to the Gentianales, the Oleacex, and Apocynaceæ. The suborders Primulales (with Myrsinaceæ6), Polemoniales (with Convolvulaceæ 2 and Solanaceæ I), Rubiales (with Caprifoliaceæ 4), and Asterales (with Compositæ I) complete the list of additions, and give us a hint as to the method of evolution.

Miocene dicotyledons included 66 families, and the species were more than seven times as many as in the Eocene. Here the petalous plants constituted 64 per cent. of the whole, of which nearly i 6 per cent. were gamopetalous. The great increase in the number of species was accompanied by a rapid multiplication and modification of previously existing types. Thus we find three more families added to Ranales, three to Caryophyllales, one to Geraniales, three to Malvales, three to Myrtales, one to Sapindales, one to Umbellales, one to Polemoniales, two to Gentianales, and one to Rubiales. The Parietales, Guttiferales, Personales, and Lamiales appear here for the first time. A closer examination of Schimper's list of Miocene plants indicates that in passing from the Eocene to the Miocene, the percentage of species of Ranales was not changed, while that of the Caryophyllales was increased, the Malvales decreased, the Primulales unchanged, the Ericales decreased, the Ebenales slightly increased, the Rosales unchanged, the Myrtales, Celastrales, and Sapindales slightly increased, the Umbellales decreased, the Rubiales and Asterales increased. If we examine the dicotyledonous vegetation of the earth today we may observe that to a limited degree these tendencies to increase or decrease are maintained to the present. This is shown in detail in the following tables (see page 153 ).

These facts are still more suggestive when presented in diagrammatic form (fig. 2. page 1 54).

After making due allowance for the imperfection of the palæontological record, and our limited knowledge concerning it, it is still safe to say that earlier dicotyledons were of considerably different types from the later, and that from period to period the relative numbers of higher types were increased. 
PERCENTAGES OF SPECIES BY SUB-ORDERS.

\begin{tabular}{|c|c|c|c|c|c|}
\hline & \multicolumn{2}{|c|}{ Cretaceous } & \multirow{2}{*}{$\begin{array}{c}\text { Eocene } \\
\text { Schimper }\end{array}$} & \multirow{2}{*}{$\begin{array}{l}\text { Miocene } \\
\text { Schimper }\end{array}$} & \multirow{2}{*}{$\begin{array}{l}\text { Present } \\
\text { Durand }\end{array}$} \\
\hline & Lesquereux & Schimper & & & \\
\hline Ranales.... . . . . . . . . . & 21.0 & I 8.0 & 8.0 & 8.0 & 3.7 \\
\hline Polygalales.............. & $\ldots$ & $\ldots$ & I. 2 & 0.2 & 0.9 \\
\hline Caryophyllales............. & 7.0 & 17.0 & 3.0 & 4.0 & 5.0 \\
\hline Geraniales, ............. & $\ldots$ & $\ldots$ & I. 2 & 2.3 & 5.0 \\
\hline Malvales........... .... & I 6.0 & I 8.0 & I 8.0 & 9.2 & 9.8 \\
\hline Rosales................. & I 1.6 & $5 \cdot 5$ & I t.O & I I.O & I I.O \\
\hline Myrtales............... & I.9 & $4 \cdot 4$ & $2 . \mathrm{I}$ & 2.7 & $7 \cdot 5$ \\
\hline Celastrales .............. & I 4.0 & I I.O & I $5 . \mathrm{I}$ & I 5.4 & 5.0 \\
\hline Sapindales.............. & 14.7 & I 6.0 & 22.0 & $24 \cdot 5$ & 2.6 \\
\hline Umbellales.............. & 6.0 & $4 \cdot 4$ & 7.0 & 2.3 & 2.3 \\
\hline Primulales. . . . . . . . . . & 2.2 & $\ldots$ & I. 8 & I.8 & 1.6 \\
\hline Ericales............... & 2.5 & I.I & 6.0 & $3 \cdot 5$ & $2, I$ \\
\hline Ebenales................ & 2.5 & I.I & 3.0 & 3.6 & I. I \\
\hline Polemoniales............ & $\ldots$ & $\ldots$ & 0.9 & $4 \cdot 3$ & 4.9 \\
\hline 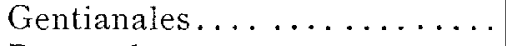 & $\ldots$ & I. I & 0.9 & $3 \cdot 5$ & 5.0 \\
\hline 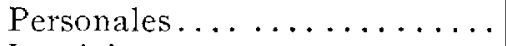 & $\cdots$ & $\ldots$ & $\ldots$ & 0.4 & 7.0 \\
\hline Lamiales.... . . . . . . . & $\ldots$ & $\ldots$ & $\ldots$ & O.I & $4 \cdot 5$ \\
\hline Rubiales............... & $\ldots$ & ... & 1.2 & I.5 & 6.0 \\
\hline Asterales............... & $\ldots$ & $\ldots$ & 0.3 & 0.9 & I 3.5 \\
\hline
\end{tabular}

PERCEN'TAGES OF SPECIES BY LARGER GROUPS.

\begin{tabular}{|c|c|c|c|c|c|c|}
\hline & \multicolumn{3}{|c|}{ Cretaceous 7} & \multirow{2}{*}{$\begin{array}{c}\text { Eocene } \\
\text { Schimper }\end{array}$} & \multirow{2}{*}{$\begin{array}{l}\text { Miocene } \\
\text { Schimper }\end{array}$} & \multirow{2}{*}{$\begin{array}{l}\text { Present } \\
\text { Durand }\end{array}$} \\
\hline & Lesq'x (I) & Lesq'x (2) & Schimper & & & \\
\hline Apetalous & $6 \mathrm{I} .0$ & 42.5 & 64.0 & 36.3 & 36.0 & I 5.5 \\
\hline Poiypetalous ...... & 34.0 & $49 \cdot 5$ & 32.0 & 49.6 & 48.0 & 36.0 \\
\hline Gamopetalous...... & 5.0 & 8.0 & 4.0 & I 4.0 & I 6.0 & 48.5 \\
\hline Thalamiflore...... & 54.7 & 44.0 & 55.0 & 30.0 & 23.5 & 27.8 \\
\hline Calyciflore ....... & 40.5 & 48.0 & 42.0 & 56.0 & $58 . \overrightarrow{6}$ & 29.5 \\
\hline Heteromera ...... & 4.7 & $5 \cdot 5$ & 2.0 & I 0.7 & 9.0 & $4 \cdot 4$ \\
\hline Bicarpellatre. ... & $\ldots$ & $\ldots$ & I.O & I.8 & 4.6 & I 9.2 \\
\hline Inferæ $\ldots \ldots \ldots \ldots$ & $\cdots$ & 2.2 & $\cdots$ & I. 5 & 2.5 & I9.I \\
\hline Ovary superior. & 86.8 & 80.0 & 80.0 & $75 \cdot 4$ & 78.7 & 65.0 \\
\hline Ovary inferior ...... & I 3.2 & 20.0 & 20.0 & 24.6 & $2 \mathrm{I} \cdot 3$ & 35.0 \\
\hline
\end{tabular}

7For comparison I have given Lesquereux's results in his "Cretaceous Flora" (I), and Flora of the Dakota Group" (2), in addition to Schimper's data. The data for the last column were taken from Durand's "Index Generum Phanerogamarum." 


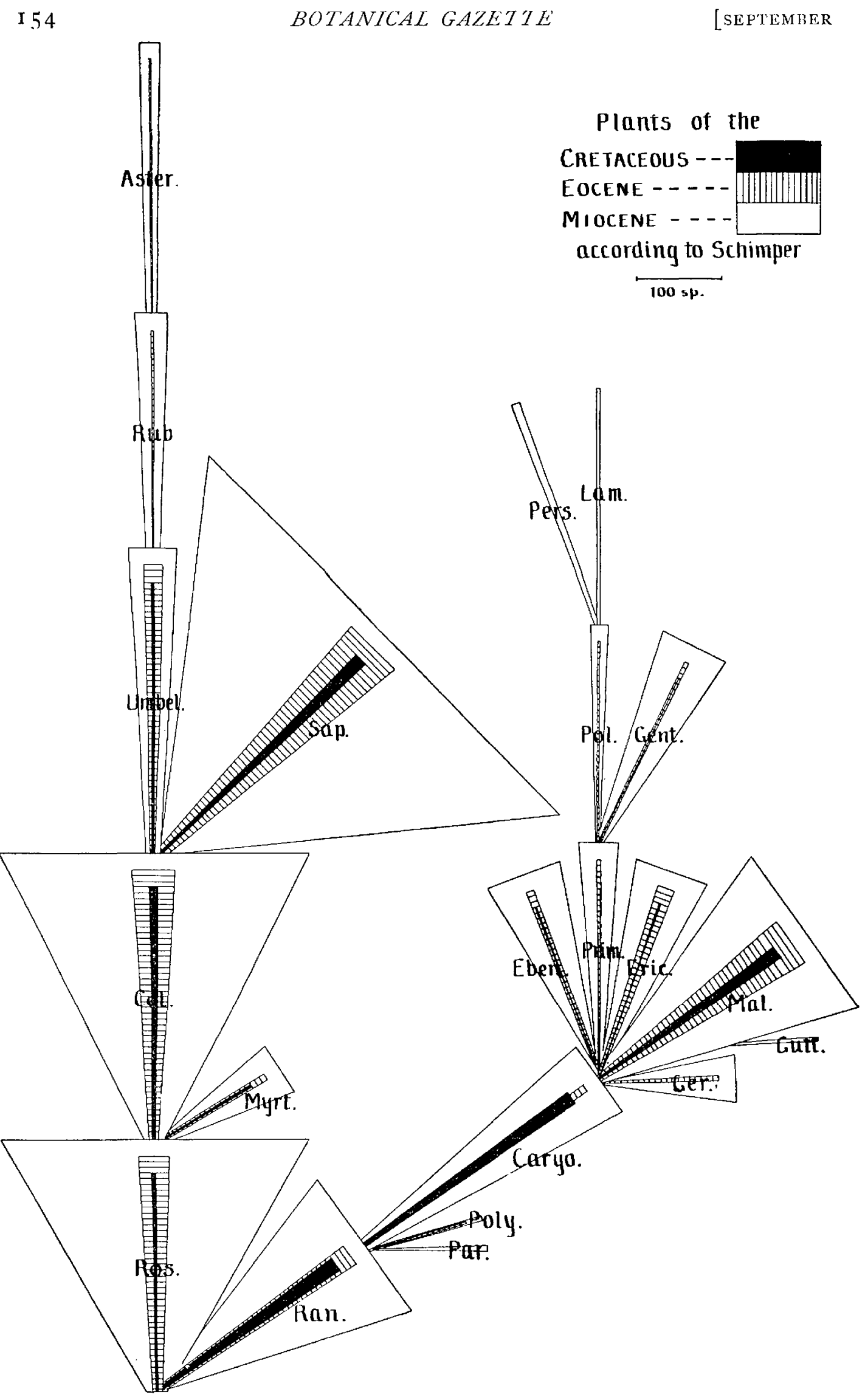

Fig. 2. Diagrammatic comparison of the Cretaceous, Eocene, and Miocene dicotyledonous floras. The widths of the triangles indicate the number of species. 
The results of a study of the plants of the Cretaceous, Eocene, Miocene, and the present may be summarized as follows:

I. It is probable that monocotyledons and dicotyledons appeared at about the same time, namely early in the Mesozoic or late in the Palæozoic.

2. The hypogynous monocotyledons appear to have preceded the epigynous monocotyledons, and similarly the petaloideous hypogynous species seem to have somewhat preceded the spadiceous and glumaceous species.

3. Apparently the Thalamifloræ and Calycifloræ are the two earlier types of the dicotyledons.

4. In the Thalamifloræ the three sub-types Ranales, Caryophyllales, and Malvales appear to be carlier than Parietales, Polygalales, Geraniales, and Guttiferales.

5. In the Calycifloræ the Rosales, Celastrales, and Sapindales are the dominant sub-types; here the second and third are greatly reduced in passing to the present, while the first maintains its position with singular persistence.

6. The Myrtales appear to be a growing sub-type, increasing rapidly in passing to the present.

7. The Umbellales, on the other hand, appear to be a waning sub-type.

8. The Heteromeræ have always been of secondary importance.

9. The Bicarpellatæ and Inferæ appear to have developed later than the other types, and to have rapidly increased to the present.

Io. In the development of the Bicarpellatæ the Polemoniales and Gentianales preceded the Personales and Lamiales.

I I. In the Inferæ the Rubiales led the Asterales.

I 2. "Polypetaly" appears to have been the common condition in the Cretaceous, Eocene, and Miocene periods.

I3. The first modification from polypetaly probably was in the direction of apetaly, a condition reached by many plants in the earlier periods, but by relatively smaller numbers in the present 
14. Gamopetaly, from small beginnings, has increased rapidly to the present.

I 5. Hypogyny has measurably decreased, while epigyny has correspondingly increased.

\section{GENERAL RESULTS FROM EMBRYOLOGY (ONTOGENY.)}

After fertilization, the oosphere in all angiosperms divides transversely into two parts, one of which becomes the so-called "suspensor," and the other the embryo proper. The suspensor segment may remain undivided, or it may undergo one or more divisions. The embryo segment at once, or after one or more longitudinal divisions, becomes divided by a transverse wall which separates the foliar (terminal) from the cauline (central) cell or cells. Soon walls form parallel to the surface of the growing embryo, giving rise to a distinct outer layer, the dermatogen, which covers all except the lowermost part of the growing plant. A little later the inner cells of the cauline portion become differentiated into plerome and periblem. Finally, the formation of the root and the root-cap are essentially the same in all angiosperm embryos.

The development of the embryo is so nearly the same in the two sub-classes, that we are compelled to admit their close relationship. The only histological difference which is measurably constant is that the longitudinal division of the embryo takes place before the formation of transverse walls in dicotyledons, and afterwards in the monocotyledons. To this general rule, however, there are numerous exceptions.

If we study the subsequent development of the embryo it is found that the terminal cell, which remains for some time undivided, usually produces a single foliar structure (cotyledon) which is situated terminally upon the caulicle, and that the terminal cell which undergoes early longitudinal division gives rise to two foliar structures (cotyledons). Whether the formation of one or two cotyledons is dependent upon the direction of the separating walls cannot bc discussed here. It is at least an interesting coincidence that in the young embryo the undivided 
foliar cell gives rise to the single cotyledon, and the divided cell, to the pair of cotyledons.

Thus far in this discussion the embryology of monocotyledons and dicotyledons indicates little more than the close relationship of the two sub-classes. Will it do more? Are there any indications which may help us to answer the question of the origin of these two groups? Have dicotyledons been derived from monocotyledons, monocotyledons from dicotyledons, or both from some common ancestor? It must be admitted that on theoretical grounds it is no more difficult to pass from two cotyledons to one, than from one to two. Indeed, there have been not a few botanists who have suggested the derivation of the monocotyledons from the dicotyledons. When, however, one compares the two embryos, there is a slight preponderance in favor of the view that the structure is a little higher in dicotyledons than in monocotyledons. The row of undivided cells in the embryo of the monocotyledon after the third or fourth segmentation is certainly a lower structure than the compact mass of cells constituting the "octant-stage" of the dicotyledonous embryo. The cotyledons themselves afford a slight suggestion as to the relationship of the two groups. It is a well established principle in embryology that embryonic stages of higher organisms resemble the adult stages of the organisms which are lower in the same genetic line. Applying this principle to the cotyledons, we observe that while they bear some similarity to the leaves of both monocotyledons and dicotyledons, the similarity is a little more marked in case of the monocotyledons. Compare the mostly sessile, often clasping, usually elongated leaves of monocotyledons with the cotyledons of either class, and contrast these with the mostly petioled, generally not clasping, and usually broad-bladed leaves of the dicotyledons.

But we must not stop with the embryo plant in this comparison. The young plant continues to pass through what are essentially embryonic stages long after it has left the seed, and begun its life as an independent organism. In the ontogeny of 
a plant there is no sharp line separating its embryonal from its subsequent life, and in the study of the development of the individual in order to make out the course of development of the species, we must follow its whole life from its beginning to its maturity. The leaves of dicotyledons present an interesting study from this standpoint. It is a well-known fact, as pointed out by Lubbock, ${ }^{8}$ that the earlier leaves are generally quite different from the later. In the young plant of the field buttercup of Europe (Ranunculus arvensis), for example, the leaves of the first node (cotyledons) are obovate or slightly spatulate; the second leaf, round-cuneate and five-toothed; the third, broadly obovate-cuneate with five large teeth; the fourth, three-parted, the divisions cuneate and three-toothed; the fifth, three-parted, the divisions cuneate, narrower below and four to five-toothed above; the sixth, three-parted, the terminal division irregularly three-lobed, the lateral divisions deeply two-parted, all the subdivisions toothed; the seventh, three-parted, the terminal division again three-parted, the lateral divisions two-parted, all the subdivisions narrow and more or less deeply and narrowly lobed. Here the earlier leaves suggest the mature foliage of Ranunculus abortivus, $R$. pygmeus, $R$. pedatifidus, $R$. pusillus, $R$. hyperboreus, and others. It does not require much study to convince one, after an examination of Lubbock's descriptions, that the young plants of different species of Ranunculus are much more alike than are the mature plants. And it is a familiar fact to those who have watched the growth of seedlings of all kinds that in general they resemble one another most when youngest, and that this resemblance becomes less and less as the plants become older. For many seedlings one can do no more when they first appear than to recognize the sub-class to which they belong; a little later the family characteristics may be made out; still later the genus is recognized; while it often happens that we must wait for the flower or even the fruit before we are able to certainly recognize the species. Sow seeds of a buttercup (Ranunculus), a clematis (Clematis), a potentilla (Potentilla),

${ }^{8}$ On seedlings 2,75 , et seq. I 892. 
a cucumber (Cucumis), a sunflower (Helianthus), a water-plantain (Alisma), an arrow-head (Sagittaria), a lily (Allium), an oat (Avena), and a wheat (Triticum), and when the young plants first appear they will be recognized merely as five dicotyledons and five monocotyledons. But a little later the buttercup, clematis, and potentilla will separate themselves from the cucumber and sunflower, the former resembling one another very much, and having a common buttercup-like look, while the latter resemble one another nearly as much. The families to which the seedlings belong will be indicated next, but it will take longer to separate the potentilla from the buttercup and clematis than the cucumber from the sunflower. The buttercup and clematis will be generically indistinguishable much longer, and had we planted seeds of different species of one of these it would have been still longer before differential characteristics would have appeared. So too with the monocotyledons, the families can be recognized long before the genera, and the genera long before the species.

Now what do these facts indicate? How can we make use of them in our present inquiry? Is it not highly probable that they indicate how and when the differentiation of species from species, of genus from genus, of family from family occurred? If we grow two plants side by side and find them to be indistinguishable until they have formed their fruits, are we not warranted in regarding the relationship a very close one, and may we not safely assume that the separation is a relatively recent accomplishment? There can be no valid objection to the rule that the greater the number of stages of identical development between plants the closer the relationship. This is but another way of expressing the common working rule of botanists that close relationship is shown by the identical structure of many organs. When we know the life history (ontogeny) of a group of plants, and have brought these together so that we shall have well wrought out the comparative ontogeny of all the species, we shall be able to indicate with much exactness their mutual relationship. And when this is done for all of the 
groups of angiosperms, their mutual relationship, also, will be indicated.

The most important suggestions as to relationship which have thus far presented themselves in embryology (ontogeny) may be summarized as follows:

I. All angiosperms are essentially alike.

2. The two sub-classes (monocotyledons and dicotyledons) appear to be modifications of a common type which diverged from one another at an early period.

3. There is no indication that either sub-class was derived from the other.

4. There are some structural indications that the monocoty ledons must rank lower than the dicotyledons.

5. The vegetative rank of most dicotyledons is so nearly the same as to have left no vestiges on the young plant, which is itself vegetative.

6. The groups into which dicotyledons and monocotyledons are divided are "flower-subdivisions" of a greatly multiplied, rather common vegetative structure; therefore, we may not expect to find upon the embryo or immature plant any vestigial record of their origin.

7. There are some minor structural modifications, as of leafshapes, serration, lobing, etc., which appear to have arisen late in the history of the species, and therefore serve as indices of specific and sometimes generic relationship.

GENERAL RESULTS FROM MORPHOLOGY.

Modern morphology concerns itself so largely with the comparative development as well as the comparative anatomy of organs as to make it impossible to draw a sharp line between it and ontogeny. It is by studying the development of organs in the immature plant, from the smallest rudiments to their full growth, that we have been able to make out their homologies. Morphology must include all of embryology and all of ontogeny.

It is needless here to take up in detail the morphology of the cells and tissues of angiosperms. It is enough to remark in 
passing that these present similar diversity of form and function in both sub-classes, and that from this fact we may infer the close relationship, if not the common origin of the monocotyledons and dicotyledons.

The tissue systems present no constant differences in the boundary and fundamental systems. Possibly the surface appendages (trichomes) reach a higher development in some dicotyledons than in any monocotyledons. The skeletal system shows some well marked differences. In monocotyledons the fibrovascular bundles are typically separate, while in dicotyledons they are typically united with one another. In the former each bundle is complete in itself, and is often sharply defined by a bounding layer of cells, while in the latter the bundles form parts of an aggregation in which the limits of the individual bundles are often indistinguishable. The shorter life of the bundle in the monocotyledons contrasts sharply with its longer life in most dicotyledons, sometimes reaching hundreds of years, as in the long-lived oaks and chestnuts. And yet these differences, sufficiently constant to characterize the sub-classes, are not invariable. There are skeletal systems in some dicotyledons whose bundles are separate, short lived, and incapable of continued growth, showing again the close relationship of the two sub-classes.

The organs of the plant body present great diversity, and their morphology has long been the subject of much study by many investigators. They may be reduced to the following types: roots, stems, foliage leaves, flower leaves, pollen leaves, ovule leaves.

Roots.-The young roots of monocotyledons are structurally simpler than those of dicotyledons. They rarely increase much in thickness or endure for any great length of time, and are usually unbranched. They contain a single central fibrovascular bundle. The roots of dicotyledons when young contain a single central bundle, but they generally develop several collateral bundles, and are thus able to increase in thickness and to endure for an indefinite time. They are commonly branched again and 
again. Here we have as a temporary condition in dicotyledons the structure which is permanent in monocotyledons.

Stems.-The young stems of monocotyledons and dicotyledons differ less than do the old stems of these sub-classes. In young stems of dicotyledons the skeletal system is composed of separate fibrovascular bundles which traverse the parenchymatous ground tissue, and at this stage the hypodermal tissues are not unlike, either in composition or arrangement. In herbaceous stems this similarity is maintained much longer than in woody stems, where the dissimilarity eventually becomes extreme. The important difference between these two types of stems is that the skeletal tissues combine to form a single solid column in the dicotyledons, while they do not in the monocotyledons. Now when to this we add the fact that the bundles of dicotyledons have fused in such a manner that their continued growth adds to the mass of the skeletal column, thus giving to the stem the possibility of indefinite increase in mass, we have again an indication of the higher rank of this sub-class.

In regard to external morphology it may be remarked that in monocotyledons there are two well defined modifications of the normal type of vegetative stem, as seen in lilies, naiads, orchids, etc. One extreme of this modification occurs in the grasses and sedges in which the internodes are greatly elongated, and the other in palms and screw-pines, in which the internodes are usually so short as to be scarcely recognizable. The suggestion which these stem modifications offer as to the relationship of grasses and sedges on the one hand, and palms and screw-pines on the other, to the lilies is obvious.

Leaves. - In general structure the leaves of angiosperms are essentially alike. The significant differences may be enumerated as follows :

I. The leaves of monocotyledons are usually entire, elongated, parallel-veined blades, placed alternately or scattered upon the stem, to which they are attached directly (in sessile leaves) or indirectly (in petioled leaves) by a commonly broad base which is rarely supplied with stipules. 
2. The leaves of dicotyledons are entire or more commonly dentate or lobed, usually broad, netted-veined blades, opposite, alternate, or scattered upon the stem, to which they are usually attached indirectly (petiolate) by a narrow base (rarely by a broad base), which is commonly supplied with stipules.

These structural differences are mainly due to differences in development. The parallelism of venation and the general absence of lobing in the leaves of monocotyledons result from the localization of growth at the base of the blade or in definite bands on each side of its axis, and commonly the netted venation in the leaves of dicotyledons results from the longer continued and more or less irregular growth of all parts of the blade; and it is to this irregularity of growth, also (especially in the peripheral portions), that the serrations, dentations, lobings, etc., are due. The development of a petiole is correlated with the assimilatory function of the leaf, and in both sub-classes is less or more, according to the degree of its illumination. The broad basal attachment in monocotyledons may depend upon the looser disposition of the fibrovascular bundles in the stems, or possibly it may indicate that leaf and stem are not yet as fully differentiated as they are in dicotyledons, a view which receives some confirmatory suggestion from the presence of an articulation at the base of the leaf in most dicotyledons, while it is absent from most monocotyledons. The significance of the stipules is not so obvious; probably their more frequent occurrence in dicotyledons is correlated with the more common development of the petiole in this sub-class.

The particular morphology of leaves is commonly indicative of relationship between species and genera, and now and then it has a broader significance. In the monocotyledons the common type of leaf is particularly modified in the sedges and grasses, this modified type being maintained with great constancy throughout the two great families. Among dicotyledons the greatly branched ("compound") leaves of mimosas (Mimosaceæ), brasilettos (Cæsalpiniaceæ), sumachs (Anacardiaceæ), walnuts (Juglandaceæ), and umbellifers (Umbelliferæ) are characteristic 
of the families, and so too are the opposite leaves of the verbenas (Verbenaceæ), mints (Labiatæ), honeysuckles (Caprifoliaceæ), and madderworts (Rubiaceæ).

Flower leaves.-The reproductive strobilus of angiosperms consists of a stem upon which are developed spore-bearing and sterile leaves. Whether the sterile leaves were originally derived from the spore-bearing ones by a process of sterilization, as suggested by Bower, 9 need not be discussed here, since such sterilization, if it ever occurred, must have taken place long before the ancestors of the angiosperms crossed the line which separates the Pteridophyta from the Spermatophyta. We have here to deal with the reproductive strobilus in the form of the flower, in which the sterile leaves are well set off from those which bear spores.

In the simpler cases the sterile leaves (perianth) are separate from one another, and this doubtless represents their primitive structure. In other cases the flower leaves have fused more or less in their growth, this doubtless being a structure derived from the simple primitive condition referred to above. In many flowers the perianth leaves show no differentiation from one another, while in others they are very unlike. In this matter it is reasonable to suppose that the primitive flower leaves were at least approximately alike in form and dimensions, and that unlikeness in these particulars arose as a modification of the primitive structure. Again we find that in many flowers the sterile leaves are in no way connected with the spore-bearing leaves, the former being attached at a distinctly lower level upon the stem. In other cases, however, there is more or less union between the sterile and spore-bearing leaves, in extreme cases amounting to complete fusion. Here again it is not hard to recognize in united and fused leaves a structure derived from the more primitive free leaves. This union of parts may receive the general designation of symphysis. ${ }^{\circ}$

Some flowers have a scanty perianth (apetalous) and others,

9 A theory of the strobilus in archegoniate plants. Ann. Bot. 8: 343 . 1894.

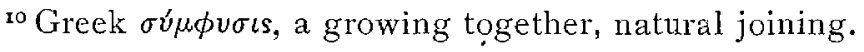


again, none at all (naked). Since these often occur on plants which are clearly related to those bearing a fully developed perianth, we are led to the conclusion that apetalous and naked flowers are modifications of the common flower structure. Thus, there can be no question as to the relationship of Clematis, Anemone, Thalictrum, Caltha, Hydrastis, etc., to Ranunculus, Myosurus, Coptis, Delphinium, and other genera of Ranunculaceæ. So, too, who questions the relationship of our apetalous maples (Acer saccharinum L. and $A$. negundo L.) to the remaining species of the genus, or of our ashes (Fraxinus sp.) to the old world petalous species? In these and many other cases we see clearly that the apetalous condition of the flower is one derived from the normal structure in which the complete perianth is present. There are, however, many apetalous dicotyledons whose relationship botanists have not been able to agree upon. Thus Bentham and Hooker in their Genera Plantarum enumerate thirtysix families, including 849 genera, and 12 , roo species, in the artificial group Monochlamydeæ, which they separate from their Polypetalæ solely by the simple (or absent) perianth; Engler and Prantl in their Pflanzenfamilien bring together into a heterogeneous group twenty-four families of mostly apetalous plants, including nearly 6000 species. All of these, excepting the Olacaceæ, are included in Bentham and Hooker's Monochlamydeæ, so that we have in Engler and Prantl's arrangement a reduction. of Monochlamyder amounting to fully one-half. This has been accomplished by a distribution of apetalous plants among those whose flower structure differs only in regard to the perianth. That this reduction could have been carried further without doing violence to our knowledge of relationship will be admitted by most systematic botanists. Thus we may readily remove the Olacaceæ, which have a perianth consisting of calyx and corolla, and with them may go the sandalworts (Santalacex), proteads (Proteaceæ), loranths (Loranthaceæ), and perhaps the balanophorads (Balanophoraceæ), all of which are more or less clearly related to the typical Celastrales. So too the willows and poplars (Salicaceæ) differ from the tamarisks (Tamaricaceæ) only 
in the absence of a perianth, the "gynæcium, placentation, ovules, fruit and seeds agreeing completely," as pointed out by Niedenzu ${ }^{\text {II }}$ in his discussion of the relationship of Tamaricaceæ.

If we were to suggest a natural classification of the dicotyledons based upon the morphology of the sterile flower leaves alone, we should group together first those plants with all their flower leaves free from one another; this would constitute our primitive group. In another place we should bring together all those in which the sterile and spore-bearing flower leaves have undergone the greatest fusion; this would constitute our highest group. Between these we should have to arrange the intermediate conditions. Then remembering that the perianth readily becomes much reduced we should have to give such place and position to each apetalous plant as its structure otherwise demanded.

Pollen leaves (microsporophylls, stamens).-The normal position of these is between the sterile and the ovule leaves. In many cases they are quite separate from one another and from the other leaves of the flower, but in many other cases they are united to one another, or to the leaves below or above.

Numerically the pollen leaves show great diversity. This is correlated with the greater or less amount of pollen required to insure the production of seeds in the different species. In general, no organs of the flower exhibit so little constancy in structure, dimensions, number, or position as the pollen leaves, and yet within narrow limits these inconstant organs often present a surprising conformity to a single type. They serve well, therefore, to define the smaller groups, but have little value as indicating broader relationships.

Ovule leaves (macrosporophylls, carpels). - These occupy the highest portion of the strobilus, and are normally separate organs, unconnected with one another or with other organs. In buttercups (Ranunculaceæ), potentillas (Rosaceæ), and waterplantains (Alismaceæ) the carpels are many and separate, while in pinks (Caryophyllaceæ), saxifrages (Saxifragaceæ), and lilies (Liliaceæ) they are more or less united with one another, thus

i ENgler and Prantl. Die Natïrlichen Pflanzenfamilien $3^{6}: 291$. 
forming a single syncarpium, the so-called "compound pistil" of descriptive botany. Many syncarpia still preserve some of their parts free from one another; thus in the saxifrages, most pinks, and some lilies, the carpels are united for only a part of their length, the terminal portions (styles) being free, while in myrtles (Myrtaceæ), primroses (Primulaceæ), and spiderworts (Commelinacex) they are fully united from end to end. All apocarpia are free from the other organs of the flower, and this is the case with many syncarpia. There are, however, many syncarpia to which some or all of the other leaves of the reproductive strobilus have become more or less completely attached. In the so-called epigynous flowers, as the irids and orchids among the monocotyledons, and the myrtles, cactuses, umbelworts, and all of the Inferæ of the dicotyledons, there has been such a fusion of the originally separate parts of the strobilus as to result in a single compact structure in which in extreme cases only the distal portions of the original leaves are distinguishable.

The primitive syncarpia of the monocotyledons appear to have contained three carpels, as in lilies, and those in dicotyledons five or more, as in pinks and mallows. In the fusion of the parts of the strobilus some of these are usually suppressed. As a result we find that in case of the greatest fusion the syncarpium contains fewer than the normal number of carpels, as for example, in the Asterales of the dicotyledons, where there are but two carpels remaining, and these so reduced as to function as but one. The genetic line which includes pinks (Caryophyllales), primroses (Primulales), phloxes (Polemoniales), figworts (Personales), and mints (Lamiales) illustrates this tendency to a reduction in the number of parts with increased fusion of the strobilar leaves. The same law is illustrated in the genetic line which includes the lilies (Coronarieæ), pipeworts (Eriocaulaceæ), sedges (Cyperaceæ), the lower grasses (Bambuseæ), and higher grasses (Agrostideæ and Paniceæ); or possibly still better in the line from lilies to amaryllids (Amaryllidaceæ), irises (Iridaceæ), burmannias (Burmanniaceæ), and orchids (Orchidaceæ). 
It will be seen from the foregoing discussion of the reproductive strobilus that there are two principal modifications to which it is subject, namely (a) symphysis, that is, a fusion of parts, and (b) aphanisis, ${ }^{12}$ a suppression of parts. These may separately or jointly affect some or all parts of the strobilus, resulting in the multitude of forms which it assumes. Aphanisis alone results in apetaly and diclinism; symphysis alone, in such a type as we find in myrtles and cactuses.

We may summarize the results from a morphological study of plants as follows:

I. The identity of the cells and tissues of the two sub-classes of angiosperms indicates their close relationship.

2. The fibrovascular tissue-system of the dicotyledons indicates that this sub-class is higher than the monocotyledons.

3. The roots of dicotyledons indicate that this sub-class is higher than monocotyledons, and suggest the possibility of the origin of the former from the latter.

4. The structure of the dicotyledonous stem indicates the higher rank of this sub-class.

5. Among monocotyledons the external morphology of the stem indicates the derivation from lily-like plants of the palms and screwpines by an excessive shortening of internodes, and of sedges and grasses by a corresponding elongation.

6. The general morphology of the leaves of monocotyledons and dicotyledons, as has already been indicated many times, emphasizes the close relationship of the two sub-classes, and repeats the suggestion that the former include plants which must take rank below the dicotyledons.

7. The particular morphology of leaves commonly indicates specific or generic relationship, but now and then they possess a sufficient constancy to serve as indices of family relationship.

8. There are two principal modifications of the flower strobilus - namely, symphysis and aphanisis-which separately or jointly affect some or all of its parts.

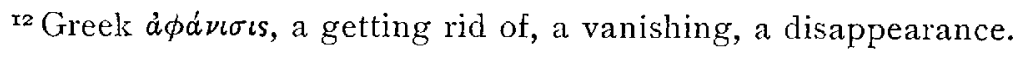


9. The perianth of separate leaves becomes modified by their fusion with one another and with other strobilar leaves (symphysis). The reduction (aphanisis) of the perianth is a modification of much less morphological significance, and is rarely, if ever, indicative of broad relationships.

IO. The pollen leaves show constancy in structure, dimensions, number, and position only within narrow limits, and therefore serve to define the smaller groups (families and tribes), but have little value as indices of broad relationships.

II. In the symphysis of the primitive apocarpous flower strobilus the carpels first unite into a syncarpium, and with this process of fusion there is generally a progressive reduction (aphanisis) in the number of constituent carpels.

I2. The extreme modification of the flower strobilus results in the fusion of all the constituent parts (symphysis) and their reduction in number (aphanisis).

From all the foregoing we may pretty safely proceed to construct the hypothetical phylogeny of the angiosperms, to serve as the basis of their taxonomy. And let it be fully understood that this is not presented as final, or as entirely satisfactory; it is merely a working hypothesis, which claims no other merit than that of an attempt at conformity to the suggestions sometimes faint, sometimes doubtful, from palæontology, from embryology (ontogeny), and from morphology. That some of these suggestions have been misinterpreted, or that others have been overlooked, is altogether likely; but in this I must beg the indulgence of systematists, who may well realize the difficulties surrounding the problem here undertaken.

HYPOTHETICAL PHYLOGENY OF ANGIOSPERMS.

The angiospermous phylum parted very early into two sub classes, the monocotyledons and dicotyledons. This separation took place while the flower strobilus was still apocarpous, and before any of the strobilar leaves had undergone much, if any, modification. At this stage the vegetative characters of the 
sporophyte were so well established that no profound modifications have been undergone since.

The modifications which gave us the main lines of monocotyledons were first the fusion of the carpels with one another and the production of a syncarpium, and second the progressive fusion of the syncarpium with the other strobilar leaves. These resulted in the phylum which begins with Apocarpa and passes to Coronarieæ, Epigynæ, and Microspermæ. In some Apocarpæ and many plants of the type of the Coronariex the perianth has been more or less reduced (by aphanisis), in some cases amounting to complete suppression, as in palms (Calycinie), aroids (Nudifloræ), and sedges and grasses (Glumaceæ).

The primitive dicotyledons were apocarpous plants which soon developed along two diverging lines, characterized in the one case by the tendency of the leaves of the strobilus to fuse with each other in a transverse direction (transverse symphysis), while in the other the tendency was to a fusion of the leaves in two directions (transverse and longitudinal symphysis). The phylum resulting from the predominance of transverse symphysis began with the apocarpous Ranales, soon developing into the syncarpous Caryophyllales and Malvales. The type of the Caryophyllales became slightly modified in the Primulales by the transverse symphysis of the inner perianth whorl resulting in gamopetaly. In the Polemoniales the type of the Primulales began to undergo modification by aphanisis, resulting in a reduction of the microsporophylls to five, and the carpels in the syncarpium to two or three. Increasing aphanisis produced the Personales and Lamiales with their four or two microsporophylls and irregular perianth, and in the latter group with each carpel restricted to the production of but one or two macrosporangia.

The phylum in which both transverse and longitudinal fusion are well marked proceeds from the apocarpous roseworts (Rosaceæ) to the syncarpous saxifrages (Saxifragaceæ) of the Rosales, to the Celastrales, in which epigyny is sometimes attained, thence to the Umbellales, where epigyny is constant, and to the Rubiales, in which gamopetaly has become a fixed 
character, culminating in the group of the Asterales with its greatly reduced bicarpellary syncarpium.

Early predominance of aphanisis in the ranal phylum soon gave rise to the apetalous laurels (Lauraceæ) and nutmegs (Myristicacex) from the buttercup type. A somewhat later appearance of aphanisis gave rise to the willows (Salicacex), amaranths (Amaranthaceæ), and buckwheats (Polygonaceæ) from the pink type; and the spurgeworts (Euphorbiacex) and nettle-worts (Urticaceæ) from them allow type. Similarly, early predominance of aphanisis in the rosal phylum gave rise to the apetalous plane-trees (Platanaceæ) from the rosewort type; while its later appearance gave rise to the proteads (Proteaceæ), daphnads (Thymelæaceæ), oleasters (Elæagnaceæ), sandalworts (Santalacex), and loranths (Loranthacex) from the holly type; and the walnuts (Juglandaceæ), oaks (Fagaceæ), and galeworts (Myricaceæ) from the horse-chestnut type (Sapindales).

Early predominance of symphysis gave rise to the peculiar group of the myrtles (Myrtales) from the rosewort type, in which by later aphanisis, hippurids (Halorageæ), birthworts (Aristolochiaceæ), vine rapes (Cytinaceæ) were produced. The Parietales and Polygalales are later developments more or less parallel to the Caryophyllales; while the Geraniales and Guttiferales stand in a similar relation to the Malvales.

\section{THE TAXONOMY OF ANGIOSPERMS.}

It should not be necessary to urge at this time the desirability of a conformity between phylogeny and taxonomy, and yet it may be well to call to mind the words of Dr. Gray:

We have supposed, and Naegeli takes a similar view, that each plant has an internal tendency or predisposition to vary in some directions rather than others; from which, under natural selection, the actual differentiations and adaptations have proceeded. Under this assumption, and taken as a working hypothesis, the doctrine of the derivation of species serves well for the coordination of all the facts in botany, and affords a probable and reasonable answer to a long series of questions which without it are totally unanswerable. It is supported by vegetable palæontology, which assures us that the plants of the later geological periods are the ancestors of the actual flora 
of the world. In accordance with it we may explain in a good degree the present distribution of species and other groups over the world. It rationally connects the order of the appearance of vegetable types in time with the grades of differentiation and complexity, both proceeding from the simpler, or lower and more general, to the higher and more differentiated or special; it explains by inheritance the existence of functionless parts; throws light upon the anomalies of parasitic plants in their various gradations, upon the assumption of the most various functions by morphologically identical organs, and indeed illuminates the whole field of morphology with which this volume has been occupied. It follows that species are not "simple curiosities of nature," to be catalogued and described merely, but that they have a history, the records of which are impressed upon their structure as well as traceable in their geographical and palæontological distribution. ${ }^{x_{3}}$

In an adjoining paragraph he tersely sums up the matter in this aphorism:

Affinity under this view is consanguinity, and classification, so far as it is natural, expresses real relationship.

We are warranted in strenuously urging a conformity of taxonomy with phylogeny, and while we must be cautious not to propose a new arrangement for every phylogenetic vagary which may arise, we must be equally careful not to allow our natural inertia, or the conveniences of the art of botany, to retard any change demanded by science.

Four years ago I discussed ${ }^{14}$ the insufficiency of the Candollean system, and a year ago that of the system of Engler and Prantl ${ }^{\text {I5 }}$ as expressions of genetic relationship. Further study of the problem and of these systems has deepened my conviction that while each is doubtless the best formula of the results of its period, neither one is today an adequate expression of our knowledge of the structure and relationship of the angiosperms. We are not to imagine, however, that the work of the past is to be thrown aside as worthless, and that the system based upon phylogeny will have nothing in common with the older systems. On the contrary, when examined critically,

×3 Structural Botany 330.

${ }^{14}$ Evolution and classification. Proc. A. A. A. S. $42: 237$.

${ }_{55}$ The point of divergence of monocotyledons and dicotyledons. Bot. GAz. 22: 229. 
the system which seems to us to be more nearly in accord with our knowledge of phylogeny does not differ as much from the two older systems as they differ from one another. It is only when we make a superficial comparison of the Candollean system (as wrought out by Bentham and Hooker) and Eichler's system (as modified by Engler and Prantl) that they seemed to be radically or even greatly different. Engler and Prantl have reduced by one-half that troublesome mass of poorly understood plants, the Apetalæ; then beginning with the Ranales and Parietales a similar sequence of choripetalous groups is taken up in each, this becoming identical near its central course, and towards its culmination in the Umbellales. The only difference in the treatment of the Gamopetalæ is that in order to emphasize relationship with the Umbellales the Inferæ are placed first in Bentham and Hooker's system, while in the system of Engler and Prantl they are placed last, the emphasis here being given to their rank as the highest of dicotyledons.

Bringing together the results of the studies of these masters as shown in their systems, and still better in their discussions of relationship under each family, and using our hypothetical phylogeny as a general guide, we find it possible to make such modifications of the two systems as will give us an arrangement which fairly agrees with the present state of our knowledge.

The angiosperms are separable into two diverging subclasses, the monocotyledons (Monocotyledonex) and the dicotyledons (Dicotyledonex), the first ranking structurally lower than the second. The monocotyledons are well divided by Bentham and Hooker into seven series, and these we may accept unchanged, with the single exception that the waterworts (Hydrocharitaceæ) should probably be removed from the Microspermæ to constitute an additional coordinate group. These eight groups, which appear to be deserving of no more than ordinal rank, should then be rearranged so as to have the following sequence, namely: Apocarpæ, Coronarieæ, Nudifloræ, Calycinæ, Glumaceæ, Hydrales, Epigynæ, Microspermæ. Here it must be understood that the Nudifloræ, Calycinæ, and Glu- 
maceæ are separate orders radiating from the present order Coronariex, and that the Hydrales constitute a diverging order from the base of the Epigynæ. The distribution (but not necessarily the exact sequence) of families among the orders may be indicated as follows:

ORDER APOCARPAE.

Families: Alismaceæ, Triurideæ, Naiadaceæ. ORDER CORONARIEE.

Families: Stemonaceæ, Liliaceæ, Pontederiaceæ, Philydraceæ, Xyridaceæ, Mayaceæ, Commelinaceæ, Rapateaceæ.

ORDER NUDIFLORE.

Families: Pandanaceæ, Cyclanthaceæ, Typhaceæ, Aroider, Lemnaceæ. ORDER CALYCINAE.

Families: Flagellariaceæ, Juncaceæ, Palmaceæ.

ORDER GLUMACEF.

Families: Eriocaulaceæ, Centrolepidiaceæ, Restiaceæ, Cyperaceæ, Gramineæ.

ORDER HYDRALES.

Family: Hydrocharitacex.

ORDER EPIGYNA.

Families: Dioscoreaceæ, Taccaceæ, Amaryllidaceæ, Iridaceæ, Hæmodoraceæ, Bromeliaceæ, Scitamineæ.

ORDER MICROSPERMÆ.

Families: Burmanniaceæ, Orchidaceæ.

The choripetalous and gamopetalous dicotyledons are divided by Bentham and Hooker into six "series," one of which, the Discifloræ, should be broken up and its families distributed elsewhere. The remaining "series," which appear to have the rank of orders, form two somewhat diverging genetic lines or phyla, each beginning with apocarpous, hypogynous, choripetalous plants, and both attaining syncarpy and gamopetaly, one remaining hypogynous, the other becoming epigynous. An attempt has been made to distribute all the apetalous plants, these having been assigned places in the lower two orders. 
Since gamopetaly has evidently been attained at more than one point, it is no longer desirable to retain the Gamopetalæ as a distinct group. It must constantly be borne in mind that these orders and their sub-orders, as well as the families, are diversely related to one another, sometimes serially, but more commonly divergently, as the twigs of a tree are related, now by direct extension, and then by lateral branching (see fig. 3 ).

It still remains to work out the particular relationship of the families to one another in the orders of monocotyledons and the sub-orders of dicotyledons, in accordance with the general prin ciples here laid down. This the present writer hopes to complete within the next year or two, having already accomplished somewhat in this direction. This will prepare the way for a natural arrangement of the genera in the families, a task which may well claim many years for its completion.

The distribution (but not necessarily the exact sequence) of the families among the orders may be indicated as follows: ${ }^{16}$

\section{ORDER THALAHIFLORA:}

Sub-order Ranales.

Families: Ranunculaceæ, Dilleniaceæ, Calycanthaceæ, Magnoliaceæ Anonaceæ, Myristicaceæ, Monimiaceæ, Chloranthaceæ, Menispermaceæ, Benberidaceæ, Lauraceæ, Nymphæaceæ.

\section{Sub-order Parietales.}

Families: Sarraceniaceæ, Papaveraceæ, Cruciferæ, Capparidaceæ, Resedaceæ, Cistaceæ, Violaceæ, Canellaceæ, Bixaceæ, Samydaceæ, Lacistemaceæ, Nepenthaceæ.

Sub-order Polygalales.

Families: Pittosporaceæ, Tremandraceæ, Polygalaceæ, Vochysiaceæ.

Sub-order Caryophyllales.

Families: Caryophyllaceæ, $>$ Frankeniaceæ, Tamaricacex, Salicaceæ; $>$ Portulacacex, Ficoidex $;>$ Phytolaccaceæ $;>$ Nyctaginacex $;>$ Illece braceæ, Amaranthaceæ, Chenopodiaceæ, Polygonaceæ ; > Batideæ (?).

${ }^{x 6}$ In some sub-orders which have been more exhaustively studied a rearrangement of the families has been made and genetic lines indicated by the sign $>$ which may be read "from whence came," each line being derived from the family first named in the sub-order. 
Sub-order Geraniales.

Families: Linaceæ, Humiriaceæ, Malpighiaceæ, Zygophyllaceæ, Geraniaceæ, Rutaceæ, Simarubaceæ, Ochnaceæ, Burseraceæ, Meliaceæ, Dichapetalaceæ.

Sub-order Guttiferales.

Families: Elatinaceæ, Hypericaceæ, Guttiferæ, Theaceæ, Dipterocarpaceæ, Chlænaceæ.

$$
\text { Sub-order Malvales. }
$$

Families: Tiliaceæ, $>$ Sterculiaceæ, Malvaceæ; >Urticaceæ, Leitneriaceæ; $>$ Euphorbiaceæ, Balanopseæ, Empetraceæ ; > Ceratophyllaceæ, Podostemaceæ ; > Piperaceæ.

\section{ORDER HETEROMERÆ.}

Sub-order Primulales.

Families: Primulaceæ, $>$ Plumbaginaceæ $;>$ Myrsinaceæ; $>$ Plantaginaceæ.

\section{Sub-order Ericales.}

Families: Ericaceæ, $>$ Vacciniaceæ; $>$ Epacridaceæ, Diapensiaceæ ; $>$ Clethraceæ, Pirolaceæ, Lennoaceæ.

Sub-order Ebenales.

Families: Sapotaceæ, Ebenaceæ, Symplocaceæ, Styracaceæ. ORDER BICARPELLATE.

Sub-order Polemoniales.

Families: Polemoniaceæ, $>$ Convolvulaceæ; $>$ Hydrophyllaceæ, Boraginaceæ, Solanaceæ.

\section{Sub-order Gentianales.}

Familics: Oleaceæ, Salvadoraceæ, Apocynaceæ, Asclepiadaceæ, Logani aceæ, Gentianaceæ.

$$
\text { Sub-order Personales. }
$$

Families: Scrophulariaceæ, Orobanchaceæ, Lentibulariaceæ, Columeliaceæ, Gesneraceæ, Bignoniaceæ, Pedaliaceæ, Acanthaceæ.

Sub-order Lamiales.

Families: Myoporaceæ, $>$ Selagineæ; > Verbenaceæ, Labiatæ.

ORDER CALYCIFLORE.

Sub-order Rosales.

Families: Rosaceæ, > Connaraceæ, Mimosaceæ, Cæsalpiniaceæ, Papilionaceæ ; > Saxifragaceæ, Crassulaceæ, Droseraceæ, Grossulariaceæ, Bruniaceæ, Hamamelidaceæ, Platanaceæ. 


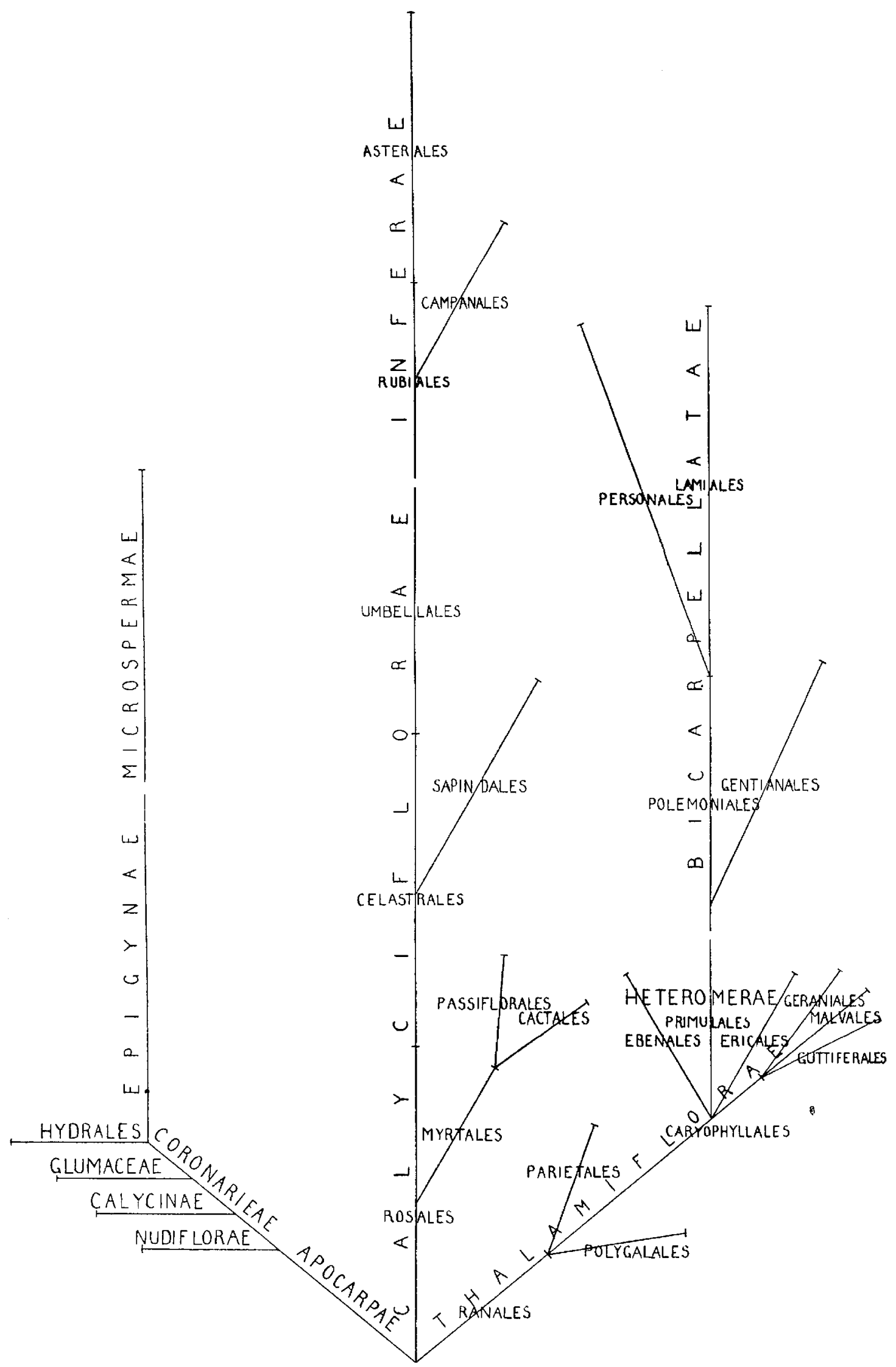

FIG. 3. Diagram to illustrate the relationship of the orders and sub-orders of angiosperms. 
Sub-order Myrtales.

Families: Lythraceæ, > Melastomaceæ, Myrtaceæ, Combretaceæ, Rhizophoraceæ; > Onagraceæ, Halorageæ ; > Aristolochiaceæ, Cytinaceæ Sub-order Passiflorales.

Families : Loasaceæ, $>$ Turneraceæ $;>$ Passifloraceæ $;>$ Cucurbitaceæ $>$ Begoniaceæ, Datiscaceæ.

\section{Sub-order Celastrales.}

Families: Rhamnaceæ, $>$ Celastraceæ, Stackhousiaceæ, Olacaceæ, Santalaceæ, Loranthaceæ, Balanophoraceæ; > Ilicineæ $;>$ Vitaceæ ; > Thymelæaceæ, Elæagnaceæ, Proteaceæ ; > Penæaceæ.

\section{Sub-order Sapindales.}

Families: Sapindaceæ, > Sabiaceæ, Anacardiaceæ, Juglandaceæ; $>$ Betulaceæ, Fagaceæ ; > Myricaceæ ; > Casuarinaceæ (?).

Sub-order Umbellales.

Families : Araliaceæ, $>$ Umbelliferæ ; $>$ Cornaceæ. ORDER INFERÆ.

Sub-order Rubiales.

Families : Rubiaceæ ; Caprifoliaceæ. ${ }^{\text {T7 }}$

Sub-order Campanales.

Families : Campanulaceæ, $>$ Goodeniaceæ, Candolleaceæ. Sub-order Asterales.

Families: Valerianaceæ, $>$ Dipsaceæ $;>$ Calyceraceæ $;>$ Compositæ. The University of Nebraska.

If It seems probable that the two families of Rubiales originated independently, the Rubiaceæ from Araliaceæ, and the Caprifoliaceæ from Cornaceæ. 